\title{
THERMODYNAMIC ANALYSIS OF THE PRECIPITATION OF CARBONITRIDES IN MICROALLOYED STEELS
}

\author{
TERMODINAMSKA ANALIZA IZLOČANJA KARBONITRIDOV V \\ MIKROLEGIRANIH JEKLIH
}

\author{
Marek Opiela \\ Silesian University of Technology, Institute of Engineering Materials and Biomaterials, Konarskiego Street 18a, 44-100 Gliwice, Poland \\ marek.opiela@polsl.pl \\ Prejem rokopisa - received: 2014-07-01; sprejem za objavo - accepted for publication: 2014-07-08
}

doi: $10.17222 / \mathrm{mit} .2014 .096$

\begin{abstract}
The production of mass-products of microalloyed steels with a high strength requires a proper adjustment of the thermomechanical processing and the kinetics of the precipitation of the MX-type $(\mathrm{M}-$ microalloying element, $\mathrm{X}-\mathrm{metalloid})$ phases in austenite. The understanding of the effect of carbonitrides on the processes of hot-working and cooling from the finishing deformation temperature requires the knowledge of the mechanism of their formation and their stability in austenite. The research was carried out on newly manufactured Ti-V and Ti-Nb-V steels for forged machine parts with thermomechanical processing. The analysis of the precipitation of the carbonitrides with the stoichiometric compositions of $\mathrm{Ti}_{x} \mathrm{~V}_{1-x} \mathrm{C}_{y} \mathrm{~N}_{1-y}$ and $\mathrm{Ti}_{x} \mathrm{Nb}_{v} \mathrm{~V}_{1-x-\nu} \mathrm{C}_{y} \mathrm{~N}_{1-y}$ was based on the Hillert-Staffanson model improved by Adrian. The effect of the austenitizing temperature in the range from $900{ }^{\circ} \mathrm{C}$ to $1200{ }^{\circ} \mathrm{C}$ on the grain size of the original austenite was investigated to verify the results of the calculation. The result provides the basis for a suitable design of the manufacturing process of the thermomechanical treatment to obtain high-strength forged elements of microalloyed steels.

Keywords: microalloyed steels, MX-type phases, thermomechanical processing
\end{abstract}

Proizvodnja masovnih izdelkov iz mikrolegiranih jekel z visoko trdnostjo zahteva pravilno prilagoditev termomehanske predelave in kinetike izločanja faze MX (M - mikrolegirni element, X - metaloid) v avstenitu. Razumevanje vpliva karbonitridov na procese vroče predelave in ohlajanja iz temperature končne deformacije zahteva poznanje mehanizma njihovega nastanka in stabilnosti v avstenitu. Raziskava je bila izvršena na novo izdelanih jeklih za odkovke Ti-V in Ti-Nb-V po postopku termomehanske obdelave. Analiza izločanja karbonitridov s stehiometrično sestavo $\mathrm{Ti}_{x} \mathrm{~V}_{1-x} \mathrm{C}_{y} \mathrm{~N}_{1-y}$ in $\mathrm{Ti}_{x} \mathrm{Nb}_{v} \mathrm{~V}_{1-x-\nu} \mathrm{C}_{y} \mathrm{~N}_{1-y}$ temelji na Hillertovem in Staffansonovem modelu, ki ga je izboljšal Adrian. Preiskovan je bil vpliv temperature avstenitizacije v območju $900{ }^{\circ} \mathrm{C}$ do $1200{ }^{\circ} \mathrm{C}$ na prvotno velikost avstenitnih zrn, da bi preverili rezultate izračunov. Rezultati omogočajo pridobitev osnove za pravilno načrtovanje postopka izdelave s termomehansko obdelavo odkovkov z veliko trdnostjo iz mikrolegiranih jekel.

Ključne besede: mikrolegirana jekla, faze vrste MX, termomehanska obdelava

\section{INTRODUCTION}

The production of metallurgical products with high mechanical properties from microalloyed steels requires the conditions of plastic working to be adjusted to the kinetics of the dissolution (precipitation) of the MX type of micro-additions introduced into steel. The solubility of the MX phases, i.e., nitrides, carbides and carbonitrides of the alloying elements such as $\mathrm{Ti}, \mathrm{Nb}, \mathrm{V}, \mathrm{Zr}$ or $\mathrm{B}$ in austenite is determined with the logarithm of the solubility product expressed with the equation: ${ }^{1-5}$

$$
\lg [M] \cdot[X]=B-A / T
$$

where $[M]$ and $[X]$ are the mass fractions of the metallic micro-addition and the metalloid dissolved in austenite at temperature $T$, respectively, $A$ and $B$ are the constants associated with the free enthalpy of the MX-phase formation. It should be noted that constants $A$ and $B$ depend on the method of determination; for this reason slightly different values for the same phase can be found in 6,7 .

High technical usability belongs to the diagrams of different MX phases dissolved in austenite, determined for different steels on the basis of Equation (1) as well as to the computer programs calculating the chemical compositions and fractions of these phases as a function of temperature. The chemical composition of austenite $([M],[X])$ and the portion of the undissolved compound can be determined using the solubility product and the mass balance of the elements included in the reaction. A simplified thermodynamic model based on the laws of thermodynamic equilibrium, concerning the precipitation of the compound, is described with a system of equations: ${ }^{8}$

$$
\begin{gathered}
{[M] \cdot[X]=k_{\mathrm{MX}}} \\
\mathrm{M}=[\mathrm{M}]+\frac{(\mathrm{M})}{(\mathrm{MX})}<\mathrm{MX}> \\
\mathrm{X}=[\mathrm{X}]+\frac{(\mathrm{M})}{(\mathrm{MX})}<\mathrm{MX}>
\end{gathered}
$$

where $k_{\mathrm{MX}}=[M] \cdot[X]$ indicates the solubility product of $M X, M$ and $X$ indicate the total concentrations of these elements in steel in mass fractions $(w / \%)$, the atomic mass of the elements, as the symbols in parentheses, ( ). 
The solution of this system of equations is a quadratic function that allows us to calculate the amount of the interstitial element dissolved in austenite:

$$
[\mathrm{X}]^{2}+[\mathrm{X}] \cdot\left[\frac{(\mathrm{X})}{(\mathrm{M})} \cdot \mathrm{M}-\mathrm{X}\right]-\frac{(\mathrm{X})}{(\mathrm{M})} k_{\mathrm{MX}}=0
$$

By avoiding the negative solution and $\Delta>0$, the equation has two solutions. However, in the case of $\Delta=$ 0 , the austenitizing temperature is higher than, or equal to, the temperature of the dissolution of the compound. The part of the interstitial element dissolved in austenite with $\Delta>0$ is determined from the following equation:

$[\mathrm{X}]=\frac{\mathrm{X}-\frac{(\mathrm{X})}{(\mathrm{M})} \cdot \mathrm{M}+\sqrt{\left(\frac{(\mathrm{X})}{(\mathrm{M})} \cdot \mathrm{M}-\mathrm{X}\right)^{2}+4 \frac{(\mathrm{X})}{(\mathrm{M})} \cdot k_{\mathrm{MX}}}}{2}$

The models of the precipitation processes in microalloyed steels, based on the laws of thermodynamic equilibrium, also include the formation of complex carbonitrides during hot working. The carbides and nitrides of the $\mathrm{Nb}$, Ti and $\mathrm{V}$ micro-additions reveal mutual solubility and, as a result of this process, carbonitrides are formed, with the chemical composition and dissolution temperature dependent on the chemistry of the steel. ${ }^{9}$ The precipitation of the complex carbonitrides with a $\mathrm{MC}_{y} \mathrm{~N}_{1-y}$ stoichiometric constitution is determined with a thermodynamic model based on the assumptions of the sublattice model created by Hillert and Staffanson ${ }^{10}$, with the basic simplifying assumption that the metallic element $\mathrm{M}$ and the interstitial elements $(\mathrm{C}, \mathrm{N})$ in the steel form dilute solutions in austenite and that their activities meet Henry's law. The final form of the equations of this model describes the state of thermodynamic equilibrium in the Fe-M-C-N system:

$$
\begin{gathered}
\ln \left(\frac{y k_{\mathrm{MC}}}{\left[\mathrm{M}_{\mathrm{a}}\right] \cdot\left[\mathrm{C}_{\mathrm{a}}\right]}\right)+(1-y)^{2} \frac{L_{\mathrm{CN}}^{\mathrm{M}}}{R T}=0 \\
\ln \left(\frac{(1-y) k_{\mathrm{MN}}}{\left[\mathrm{M}_{\mathrm{a}}\right] \cdot\left[\mathrm{N}_{\mathrm{a}}\right]}\right)+y^{2} \frac{L_{\mathrm{CN}}^{\mathrm{M}}}{R T}=0
\end{gathered}
$$

where $\left[M_{\mathrm{a}}\right],\left[N_{\mathrm{a}}\right]$ and $\left[C_{\mathrm{a}}\right]$ indicate the atomic fractions of the metallic element $[\mathrm{M}]$ and interstitial elements $[\mathrm{N}]$ and [C] dissolved in austenite, $k_{\mathrm{MN}}$ and $k_{\mathrm{MC}}$ indicate the reaction equilibrium constants, $L^{\mathrm{M}} \mathrm{CN}$ is the interaction parameter of the $\mathrm{M}$ element affecting $\mathrm{C}-\mathrm{N}$, and the $y$ and $(1-y)$ solutions indicate the $M C$ and $M N$ moles, respectively. The system of Equations (7) and (8) contains four unknowns: $\left[M_{\mathrm{a}}\right],\left[N_{\mathrm{a}}\right],\left[C_{\mathrm{a}}\right]$ and $y$. In the solutions based on the mass balance of carbonitrides, the following reactions are used:

$$
\begin{aligned}
& \mathrm{M}_{\mathrm{a}}=\frac{f}{2}+(1-f)\left[\mathrm{M}_{\mathrm{a}}\right] \\
& \mathrm{C}_{\mathrm{a}}=\frac{y f}{2}+(1-f)\left[\mathrm{C}_{\mathrm{a}}\right]
\end{aligned}
$$

$$
\mathrm{N}_{\mathrm{a}}=\frac{(1-y) f}{2}+(1-f)\left[\mathrm{N}_{\mathrm{a}}\right]
$$

with the amount fraction of the $\mathrm{MC}_{y} \mathrm{~N}_{1-\mathrm{y}}$ precipitations.

Complex $\mathrm{M}_{x}{ }_{x} \mathrm{M}{ }_{1-x} \mathrm{C}_{y} \mathrm{~N}_{1-y}$ or $\mathrm{M}_{x}{ }_{x} \mathrm{M}^{\prime}{ }_{\nu} \mathrm{M}^{\prime}{ }^{\prime}{ }_{1-x-y} \mathrm{C}_{y} \mathrm{~N}_{1-y}$ type carbonitrides can be formed in microalloyed steels containing two or three micro-additions (M', M", M"') at the same time. A thermodynamic model describing the state of thermodynamic equilibrium in steel containing up to three micro-additions and $\mathrm{Al}$ was elaborated by Adrian ${ }^{11,12}$. It can calculate the chemical composition of austenite and the concentration of carbonitride in a $\mathrm{Fe}-\mathrm{Nb}-\mathrm{V}-\mathrm{Ti}-\mathrm{Al}-\mathrm{C}-\mathrm{N}$ multicomponent system. The final form of the equations determining the thermodynamic equilibrium of the Fe-M'-M"-M"'Al-C-N system is as follows: ${ }^{13}$

$$
\begin{aligned}
& y \ln \frac{x y k_{\mathrm{M}^{\prime} \mathrm{C}}}{\left[\mathrm{M}_{\mathrm{a}}^{\prime}\right] \cdot\left[\mathrm{C}_{\mathrm{a}}\right]}+(1-y) \ln \frac{x(1-y) k_{\mathrm{M}^{\prime} \mathrm{N}}}{\left[\mathrm{M}_{\mathrm{a}}^{\prime}\right] \cdot\left[\mathrm{N}_{\mathrm{a}}\right]}+ \\
& +y(1-y) \frac{L_{\mathrm{CN}}}{R T}=0 \\
& y \ln \frac{v y k_{\mathrm{M}^{\prime \prime} \mathrm{C}}}{\left[\mathrm{M}_{\mathrm{a}}{ }\right] \cdot\left[\mathrm{C}_{\mathrm{a}}\right]}+(1-y) \ln \frac{v(1-y) k_{\mathrm{M}^{\prime \prime} \mathrm{N}}}{\left[\mathrm{M}_{\mathrm{a}}{ }^{\prime}\right] \cdot\left[\mathrm{N}_{\mathrm{a}}\right]}+ \\
& +y(1-y) \frac{L_{\mathrm{CN}}}{R T}=0 \\
& y \ln \frac{(1-x-v) y k_{\mathrm{M}^{\prime \prime} \mathrm{C}}}{\left[\mathrm{M}_{\mathrm{a}}^{\prime \prime}{ }_{\mathrm{a}}\right] \cdot\left[\mathrm{C}_{\mathrm{a}}\right]}+(1-y) \ln \frac{(1-x-v)(1-y) k_{\mathrm{M}^{\prime \prime} \mathrm{N}}}{\left[\mathrm{M}_{\mathrm{a}}^{\prime \prime}\right] \cdot\left[\mathrm{N}_{\mathrm{a}}\right]}+ \\
& +y(1-y) \frac{L_{\mathrm{CN}}}{R T}=0 \\
& v y \ln \frac{x\left[\mathrm{M}^{\prime \prime}{ }_{\mathrm{a}}\right] k_{\mathrm{M}^{\prime} \mathrm{C}}}{v\left[\mathrm{M}_{\mathrm{a}}\right] k_{\mathrm{M}^{\prime} \mathrm{C}}}+(1-x-v)(1-y) \ln \frac{(1-x-v)\left[\mathrm{M}^{\prime}{ }_{\mathrm{a}}\right] k_{\mathrm{M}^{\prime} \mathrm{N}}}{X\left[\mathrm{M}^{\prime \prime \prime}{ }_{\mathrm{a}}\right] k_{\mathrm{M}^{\prime} \mathrm{N}}} \\
& +(1-y) \ln \frac{x(1-y) k_{\mathrm{M}^{\prime} \mathrm{N}}}{\left[\mathrm{M}_{\mathrm{a}}^{\prime}\right] \cdot\left[\mathrm{N}_{\mathrm{a}}\right]}+y^{2}(1-y) \frac{L_{\mathrm{CN}}}{R T}=0 \\
& {\left[\mathrm{Al}_{\mathrm{a}}\right] \cdot\left[\mathrm{N}_{\mathrm{a}}\right]=k_{\mathrm{AIN}}}
\end{aligned}
$$

The system of equations consists of eleven unknowns describing the chemical compositions of $\left[\mathrm{M}_{\mathrm{a}}{ }_{\mathrm{a}}\right],\left[\mathrm{M}_{\mathrm{a}}\right]$, $\left[\mathrm{M}{ }^{\prime}{ }_{\mathrm{a}}\right],\left[\mathrm{Al}_{\mathrm{a}}\right],\left[\mathrm{C}_{\mathrm{a}}\right],\left[\mathrm{N}_{\mathrm{a}}\right]$ of austenite and $(x, v, y)$ carbonitrides. The subsequent equations, describing the law of conservation of mass during the reaction of the carbonitride and nitride AlN formations are necessary for the solution:

$$
\begin{aligned}
\mathrm{M}_{\mathrm{a}}^{\prime} & =\frac{x}{2} f+\left(1-f-f_{\mathrm{a}}\right)\left[\mathrm{M}_{\mathrm{a}}{ }\right] \\
\mathrm{M}_{\mathrm{a}}^{\prime \prime} & =\frac{v}{2} f+\left(1-f-f_{\mathrm{a}}\right)\left[\mathrm{M}_{\mathrm{a}}^{\prime \prime}\right] \\
\mathrm{M}^{\prime \prime \prime}{ }_{\mathrm{a}} & =\frac{z}{2} f+\left(1-f-f_{\mathrm{a}}\right)\left[\mathrm{M}^{\prime \prime \prime}{ }_{\mathrm{a}}\right] \\
\mathrm{C}_{\mathrm{a}} & =\frac{y}{2} f+\left(1-f-f_{\mathrm{a}}\right)\left[\mathrm{C}_{\mathrm{a}}\right]
\end{aligned}
$$




$$
\begin{aligned}
& \mathrm{N}_{\mathrm{a}}=\frac{1-y}{2} f+\left(1-f-f_{\mathrm{a}}\right)\left[\mathrm{N}_{\mathrm{a}}\right] \\
& \mathrm{Al}_{\mathrm{a}}=\frac{f_{\mathrm{a}}}{2} f+\left(1-f-f_{\mathrm{a}}\right)\left[\mathrm{Al}_{\mathrm{a}}\right]
\end{aligned}
$$

where $f$ is the amount fraction of carbonitride, $f_{\mathrm{a}}$ is the amount fraction of nitride $\mathrm{AlN}, k_{\mathrm{MX}}$ is the product of the MX compound solubility converted into amount fractions $\left(x_{\mathrm{MX}} / \%\right)$, the values in square brackets [ ] indicate the concentrations of the elements in the solution in amount fractions (\%), the values in parentheses ( ) indicate the atomic mass of the elements and the values without any brackets indicate the total concentrations of the elements in steel in mount fractions (\%).

The input data for the solution of the above system of equations are: the chemical composition of steel, the austenitizing temperature, the $k_{\mathrm{Mx}}$ product of the solubility of simple carbides and nitrides, MX, the parameter of the impact of the M element on the C-N solution, $L_{\mathrm{CN}}$ $=-4260 \mathrm{~J} / \mathrm{mol}$, and the $R$ gas constant.

The presented model can be used for the solutions of the technological problems associated with the production of microalloyed steels, by designing and modifying chemical compositions. The calculation involves the following parameters: the chemical composition of austenite, the chemical composition and the fraction of carbonitrides and the dissolving temperature of carbonitrides.

\section{EXPERIMENTAL PROCEDURE}

The research was performed on newly manufactured microalloyed steels (Table 1). Steels with the weight of $100 \mathrm{~kg}$ were molten in a VSG-100 type laboratory vacuum-induction PVA TePla AG furnace. The steels were cast in argon, forming square ingots with the dimensions of $160 / 140 \mathrm{~mm} \times 640 \mathrm{~mm}$ and hot worked to $32 \mathrm{~mm} \times 160 \mathrm{~mm}$ flat bars, by open die forging in a high-speed hydraulic press, applying a force of $300 \mathrm{MN}$. The range of the forging temperature was $1200-900{ }^{\circ} \mathrm{C}$.

The thermodynamic analysis of the equilibrium of the structural constituents in the stable austenite of the steels mainly focused on the analytic calculations of the austenite chemical composition, and the amounts and chemical compositions of the potential interstitial phases of carbides, nitrides or complex carbonitrides, performed as a function of the heating or cooling temperature. Also, the calculations based on the Hillert-Staffanson thermodynamic model developed by Adrian for the analysis of interstitial complex phases were conducted. For the calculation of the chemical composition of austenite and the concentration of carbonitride based on the chemistry of the analyzed microalloyed steels, CarbNit ${ }^{11}$, the computer program operating in a Delphi environment was used.

To verify the performed analysis, the effect of the austenitizing temperature on the austenite grain size was investigated. The samples of $25 \mathrm{~mm} \times 20 \mathrm{~mm} \times 32 \mathrm{~mm}$ were austenitized at the temperatures of $(900,1000$, 1100 and 1200 ) ${ }^{\circ} \mathrm{C}$ for $30 \mathrm{~min}$ and water-quenched. To reveal the grain boundaries, the samples were etched in a saturated water solution of picric acid with an addition of $\mathrm{CuCl}_{2}$ at a temperature of $60{ }^{\circ} \mathrm{C}$. The metallographic observations of the etched specimens were carried out using a Leica MEF 4A light microscope applying the magnifications of 200-800-times.

\section{RESULTS AND DISCUSSION}

The micro-additions of $\mathrm{Nb}, \mathrm{Ti}$ and $\mathrm{V}$ in the investigated steels form carbides, nitrides or simple and complex carbonitrides, most often with a $\mathrm{NaCl}$ cubic lattice and complete intersolubility. These phases nucleated both heterogeneously, on the existing precipitates such as $\mathrm{TiN}$ and $\mathrm{TiC}$ created at an increased temperature, and in a homogeneous, independent way.

The concentration of $\mathrm{Ti}$ in the examined steel was selected to bond with all the nitrogen. For this reason, $\mathrm{VN}, \mathrm{NbN}$ and AlN were not included in the thermodynamic analysis of the single interstitial phases. In addition, AlN does not dissolve in carbonitrides as it has a different, hexagonal lattice. The solubility of particular phases of the austenite of microalloyed steels is determined with the logarithmic dependence (Equation 1). The calculated solubility temperatures of the investigated phases, formed in the examined A and B microalloyed steels are listed in Table 2 with respect to the solubility products of the $\mathrm{TiN}, \mathrm{TiC}$ and $\mathrm{VC}$ type phases precipitated in steel $\mathrm{A}$ and also of $\mathrm{NbC}$ in steel $\mathrm{B}$. The maxi-

Table 2: Summary of the solubility temperatures of individual interstitial phases

Tabela 2: Pregled temperature topnosti posameznih intersticijskih faz

\begin{tabular}{|c|c|c|c|c|c|}
\hline \multirow{2}{*}{ No. } & \multirow{2}{*}{$\begin{array}{c}\text { Type of } \\
\text { MX phase }\end{array}$} & \multicolumn{2}{|c|}{$\begin{array}{c}\text { Constants in Equation } \\
(1)\end{array}$} & \multicolumn{2}{|c|}{$\begin{array}{c}\text { Solubility } \\
\text { temperature, }{ }^{\circ} \mathrm{C}\end{array}$} \\
\cline { 3 - 6 } & & $A$ & $B$ & Steel A & Steel B \\
\hline 1. & $\mathrm{TiN}$ & 15490 & 5.19 & 1350 & 1331 \\
\hline 2. & $\mathrm{TiC}$ & 10745 & 5.33 & 1188 & 1167 \\
\hline 3. & $\mathrm{NbC}$ & 7900 & 3.42 & - & 1137 \\
\hline 4. & $\mathrm{VC}$ & 9500 & 6.72 & 734 & 776 \\
\hline
\end{tabular}

Table 1: Chemical compositions of the investigated steels in mass fractions, $w / \%$

\begin{tabular}{|c|c|c|c|c|c|c|c|c|c|c|c|c|c|}
\hline \multirow{2}{*}{ Steel } & \multicolumn{13}{|c|}{ Mass fractions, $w / \%$} \\
\hline & $\mathrm{C}$ & $\mathrm{Mn}$ & $\mathrm{Si}$ & $\mathrm{P}$ & $\mathrm{S}$ & $\mathrm{Cr}$ & $\mathrm{Ni}$ & Mo & $\mathrm{Nb}$ & $\mathrm{Ti}$ & $\mathrm{V}$ & $\mathrm{B}$ & $\mathrm{Al}$ \\
\hline A & 0.31 & 1.45 & 0.30 & 0.006 & 0.004 & 0.26 & 0.11 & 0.22 & - & 0.033 & 0.008 & 0.003 & 0.040 \\
\hline $\mathrm{B}$ & 0.28 & 1.41 & 0.29 & 0.008 & 0.004 & 0.26 & 0.11 & 0.22 & 0.027 & 0.028 & 0.019 & 0.003 & 0.025 \\
\hline
\end{tabular}

Tabela 1: Kemijska sestava preiskovanih jekel v masnih deležih, w/\% 

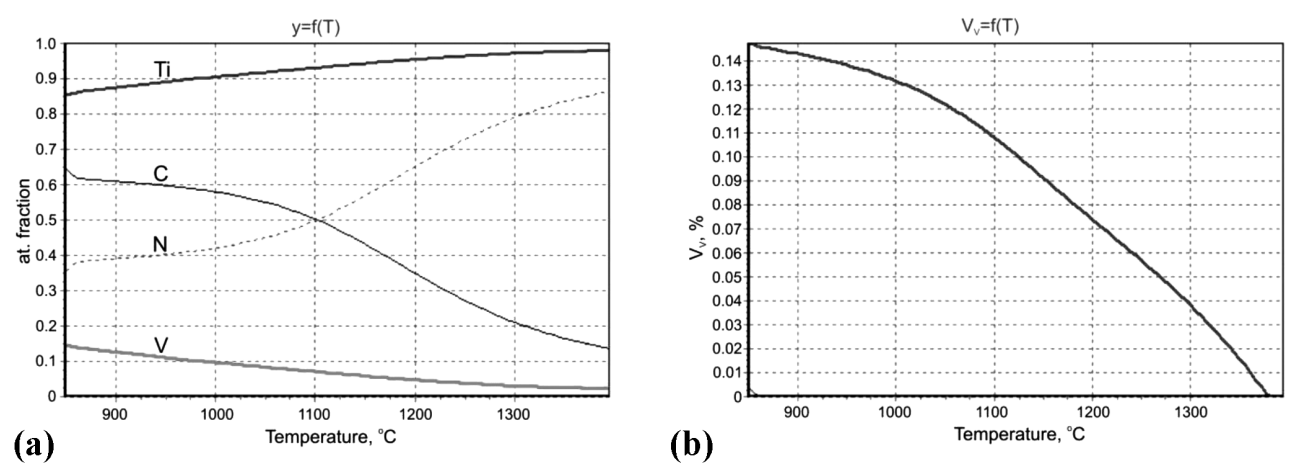

(a) $[\mathrm{M}]=\mathrm{f}(\mathrm{T})$

(b)
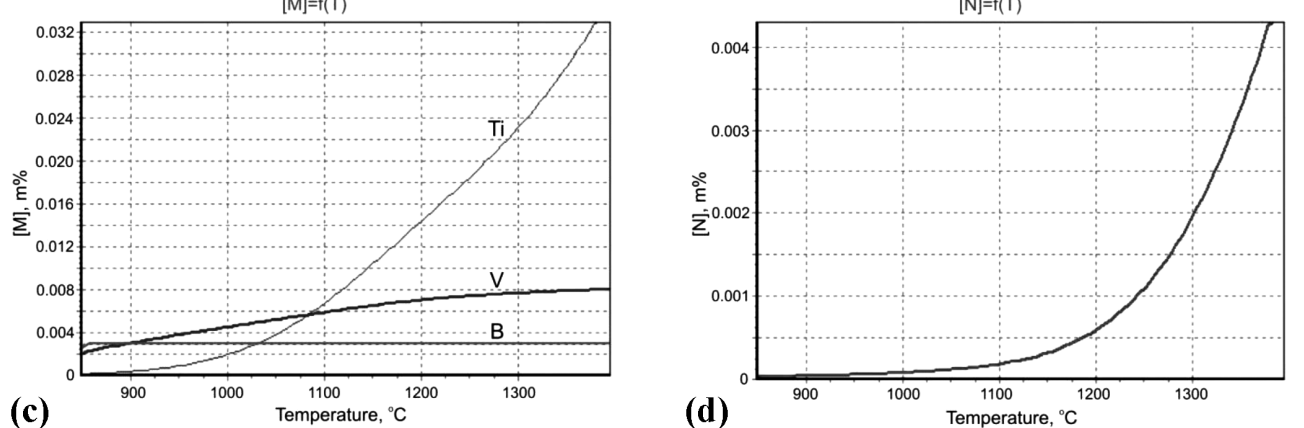

Figure 1: Calculation results for: a) $\mathrm{Ti}_{x} \mathrm{~V}_{1-x} \mathrm{C}_{y} \mathrm{~N}_{1-y}$ carbonitride, $\left.y=f(T), \mathrm{b}\right)$ volume fraction of $(\mathrm{Ti}, \mathrm{V})(\mathrm{C}, \mathrm{N})$ carbonitride and $\mathrm{BN}, V_{\mathrm{V}}=f(T), \mathrm{c}$, d) elements dissolved in austenite: $[M]=f(T)$ and $[N]=f(T)$; steel A

Slika 1: Rezultati izračunov: a) $\mathrm{Ti}_{\mathrm{x}} \mathrm{V}_{1-x} \mathrm{C}_{y} \mathrm{~N}_{1-y}$ karbonitrid, $y=f(T)$, b) volumenski delež $(\mathrm{Ti}, \mathrm{V})(\mathrm{C}, \mathrm{N})$ karbonitrida in $\mathrm{BN}, V_{\mathrm{V}}=f(T)$, c, d) elementi, raztopljeni v avstenitu: $[M]=f(T)$ in $[N]=f(T)$; jeklo A

mum solubility temperatures of the TiN type interstitial phases in the $\gamma$ base were $1350{ }^{\circ} \mathrm{C}$ and $1331{ }^{\circ} \mathrm{C}$ for the $\mathrm{A}$ and $\mathrm{B}$ steels, respectively. Thus, it is assumed that a high austenitizing temperature - close to $1200{ }^{\circ} \mathrm{C}$ - does not cause a significant grain growth of the austenite through the undissolved TiN fraction and the high heating and forging temperatures increase the durability of forging tools.

The $\mathrm{NbC}$ carbide in the austenite of the B steel with the maximum solubility temperature of $1137{ }^{\circ} \mathrm{C}$ contributes essentially to the steel strengthening through a grain refinement and precipitation hardening with a simultaneous decrease in the ductile-to-brittle-transition temperature. In turn, the VC carbide is completely dissolved in the austenite of the examined steels in the range of hot-working temperature.

Due to the mutual solubility of the interstitial phases, a complex $\mathrm{Ti}_{x} \mathrm{~V}_{1-x} \mathrm{C}_{y} \mathrm{~N}_{1-y}$ carbonitride can form in steel $\mathrm{A}$ with the micro-additions of $\mathrm{Ti}$ and $\mathrm{V}$, under the conditions of thermodynamic equilibrium, and a $\mathrm{Ti}_{x} \mathrm{Nb}_{v} \mathrm{~V}_{1-x-\nu} \mathrm{C}_{y} \mathrm{~N}_{1-y}$ complex carbonitride forms in the $\mathrm{B}$ steel with the micro-additions of $\mathrm{Ti}, \mathrm{Nb}$ and $\mathrm{V}$ (Table 3 ). The calculation results of the chemical composition of the austenite of the examined microalloyed steels, namely, the determination of the temperature dependence of the amounts of the metallic element $[M]=f(T)$ and non-metallic element $[N]=f(T)$, as well as the assumed chemical constitution of the $\mathrm{Ti}_{x} \mathrm{~V}_{1-x} \mathrm{C}_{y} \mathrm{~N}_{1-y}$ and $\mathrm{Ti}_{x} \mathrm{Nb}_{v} \mathrm{~V}_{1-x-v} \mathrm{C}_{y} \mathrm{~N}_{1-y}$ type complex carbonitrides as $y=f(T)$ with the defined volume fractions of the analyzed $V_{\mathrm{V}}=$ $f(T)$ phases are depicted in Figures $\mathbf{1}$ and 2.

Table 3: Calculated stoichiometric thermodynamic-equilibrium compositions of complex carbonitrides in the investigated steels

Tabela 3: Izračunane stehiometrične termodinamsko ravnotežne sestave kompleksnih karbonitridov v preiskovanih jeklih

\begin{tabular}{|c|c|c|c|}
\hline \multirow[b]{2}{*}{ No. } & \multirow{2}{*}{$\begin{array}{c}\text { Tempe- } \\
\text { rature } \\
{ }^{\circ} \mathrm{C}\end{array}$} & \multicolumn{2}{|c|}{ Type of carbonitrides } \\
\hline & & Steel A & Steel B \\
\hline 1 & 850 & $\mathrm{Ti}_{0.854} \mathrm{~V}_{0.146} \mathrm{C}_{0.645} \mathrm{~N}_{0.355}$ & $\begin{array}{c}\mathrm{Ti}_{0.600} \mathrm{Nb}_{0.292} \mathrm{~V}_{0.108} \mathrm{C}_{0.748} \\
\mathrm{~N}_{0.252}\end{array}$ \\
\hline 2 & 900 & $\mathrm{Ti}_{0.874} \mathrm{~V}_{0.126} \mathrm{C}_{0.610} \mathrm{~N}_{0.390}$ & $\begin{array}{c}\mathrm{Ti}_{0.646} \mathrm{Nb}_{0.301} \mathrm{~V}_{0.053} \mathrm{C}_{0.697} \\
\mathrm{~N}_{0.303}\end{array}$ \\
\hline 3 & 950 & $\mathrm{Ti}_{0.890} \mathrm{~V}_{0.110} \mathrm{C}_{0.598} \mathrm{~N}_{0.402}$ & $\begin{array}{c}\mathrm{Ti}_{0.668} \mathrm{Nb}_{0.308} \mathrm{~V}_{0.024} \mathrm{C}_{0.680} \\
\mathrm{~N}_{0.320}\end{array}$ \\
\hline 4 & 1000 & $\mathrm{Ti}_{0.904} \mathrm{~V}_{0.096} \mathrm{C}_{0.580} \mathrm{~N}_{0.420}$ & $\begin{array}{c}\mathrm{Ti}_{0.681} \mathrm{Nb}_{0.300} \mathrm{~V}_{0.019} \mathrm{C}_{0.662} \\
\mathrm{~N}_{0.338}\end{array}$ \\
\hline 5 & 1050 & $\mathrm{Ti}_{0.917} \mathrm{~V}_{0.083} \mathrm{C}_{0.550} \mathrm{~N}_{0.450}$ & $\begin{array}{c}\mathrm{Ti}_{0.705} \mathrm{Nb}_{0.282} \mathrm{~V}_{0.013} \mathrm{C}_{0.628} \\
\mathrm{~N}_{0.372}\end{array}$ \\
\hline 6 & 1100 & $\mathrm{Ti}_{0.930} \mathrm{~V}_{0.070} \mathrm{C}_{0.502} \mathrm{~N}_{0.498}$ & $\begin{array}{c}\mathrm{Ti}_{0.736} \mathrm{Nb}_{0.258} \mathrm{~V}_{0.006} \mathrm{C}_{0.578} \\
\mathrm{~N}_{0.422}\end{array}$ \\
\hline 7 & 1150 & $\mathrm{Ti}_{0.942} \mathrm{~V}_{0.058} \mathrm{C}_{0.432} \mathrm{~N}_{0.568}$ & $\mathrm{Ti}_{0.786} \mathrm{Nb}_{0.214} \mathrm{C}_{0.481} \mathrm{~N}_{0.519}$ \\
\hline 8 & 1200 & $\mathrm{Ti}_{0.954} \mathrm{~V}_{0.046} \mathrm{C}_{0.349} \mathrm{~N}_{0.651}$ & $\mathrm{Ti}_{0.851} \mathrm{Nb}_{0.149} \mathrm{C}_{0.350} \mathrm{~N}_{0.650}$ \\
\hline 9 & 1250 & $\mathrm{Ti}_{0.963} \mathrm{~V}_{0.037} \mathrm{C}_{0.272} \mathrm{~N}_{0.728}$ & $\mathrm{Ti}_{0.897} \mathrm{Nb}_{0.103} \mathrm{C}_{0.244} \mathrm{~N}_{0.756}$ \\
\hline 10 & 1300 & $\mathrm{Ti}_{0.970} \mathrm{~V}_{0.030} \mathrm{C}_{0.210} \mathrm{~N}_{0.790}$ & $\mathrm{Ti}_{0.915} \mathrm{Nb}_{0.085} \mathrm{C}_{0.180} \mathrm{~N}_{0.820}$ \\
\hline 11 & 1350 & $\mathrm{Ti}_{0.975} \mathrm{~V}_{0.025} \mathrm{C}_{0.165} \mathrm{~N}_{0.835}$ & $\mathrm{Ti}_{0.923} \mathrm{Nb}_{0.077} \mathrm{C}_{0.146} \mathrm{~N}_{0.854}$ \\
\hline
\end{tabular}

The analysis of thermodynamic equilibrium leads to the conclusion that the volume fraction $V_{\mathrm{v}}(T)$ of $\mathrm{Ti}_{0.978} \mathrm{~V}_{0.022} \mathrm{C}_{0.146} \mathrm{~N}_{0.854}$ increases with a decrease in the temperature to approximately amount fraction $0.15 \%$ at $850{ }^{\circ} \mathrm{C}$ in steel A, cooled from $1378{ }^{\circ} \mathrm{C}$ (Figure 1). The 

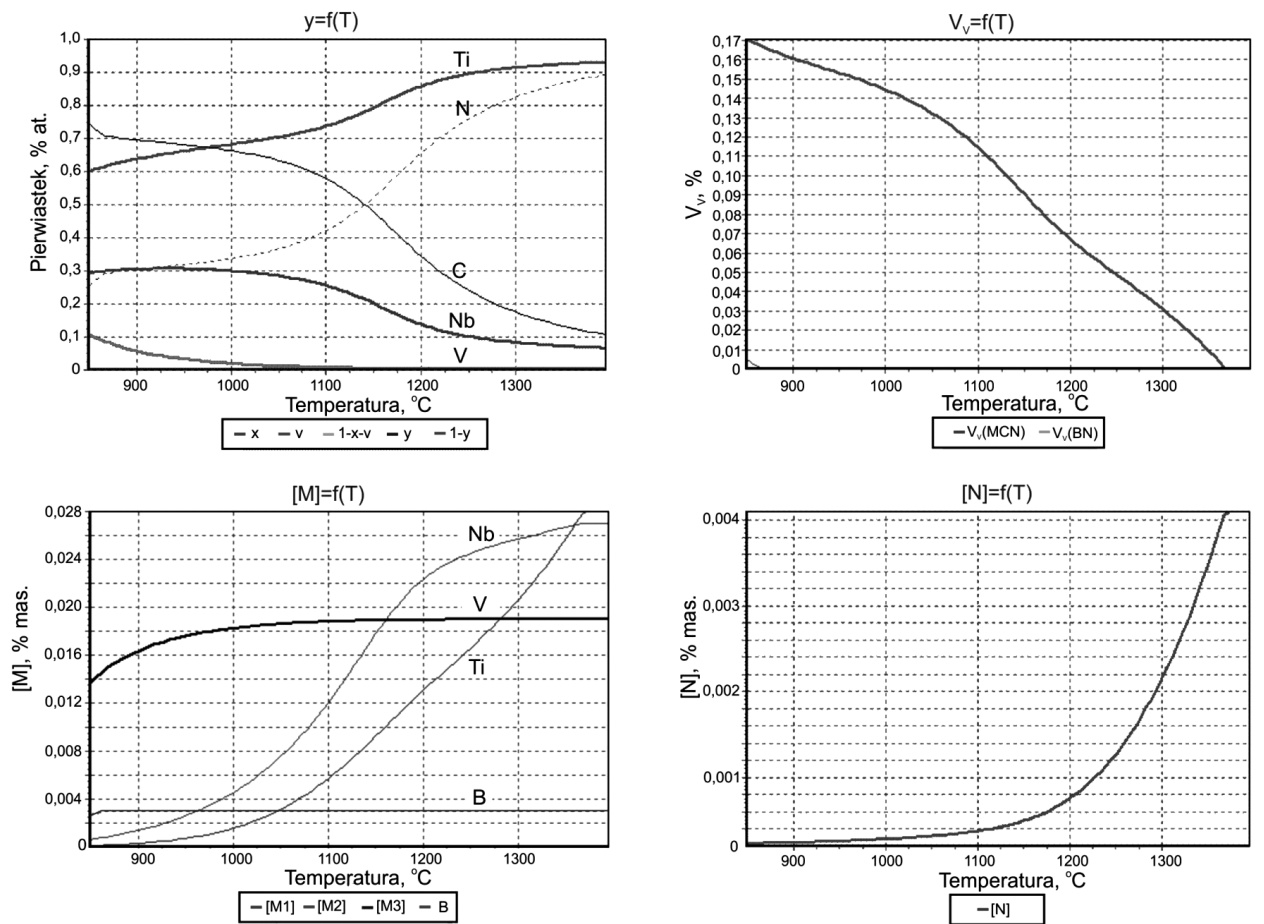

Figure 2: Calculation results of the chemical compositions of: a) $\mathrm{Ti}_{x} \mathrm{Nb}_{y} \mathrm{~V}_{1-x-\nu} \mathrm{C}_{y} \mathrm{~N}_{1-y}$ carbonitride, $y=f(T)$, b) volume fraction of $(\mathrm{Ti}, \mathrm{Nb}, \mathrm{V})(\mathrm{C}$, N) carbonitride and $\left.\mathrm{BN}, V_{\mathrm{V}}=f(T), \mathrm{c}, \mathrm{d}\right)$ elements dissolved in austenite: $[M]=f(T)$ and $[N]=f(T)$; steel B

Slika 2: Rezultati izračunov kemijske sestave: a) $\mathrm{Ti}_{x} \mathrm{Nb}_{v} \mathrm{~V}_{1-x-v} \mathrm{C}_{y} \mathrm{~N}_{1-\gamma}$ karbonitrid, $y=f(T)$, b) volumenski delež $(\mathrm{Ti}, \mathrm{Nb}, \mathrm{V})(\mathrm{C}, \mathrm{N})$ karbonitrida in $\left.\mathrm{BN}, V_{\mathrm{V}}=f(T), \mathrm{c}, \mathrm{d}\right)$ elementi, raztopljeni v avstenitu: $[M]=f(T)$ in $[N]=f(T)$; jeklo B

amount of $\mathrm{V}$ in the carbonitride increases from amount fractions $0.02 \%$ to $0.15 \%$ cooled from $1378{ }^{\circ} \mathrm{C}$ to 850 ${ }^{\circ} \mathrm{C}$. In the temperature range from $1378{ }^{\circ} \mathrm{C}$ to $856{ }^{\circ} \mathrm{C}$, the amount of carbon in the carbonitride increases from amount fractions $0.14 \%$ to $0.65 \%$, while in the same temperature range the amount of nitrogen decreases from amount fractions $0.85 \%$ to $0.36 \%$. At $1100{ }^{\circ} \mathrm{C}$, the amounts of $\mathrm{C}$ and $\mathrm{N}$ are similar, being $0.502 \%$ and $0.498 \%$, respectively. The calculated stoichiometric compositions, in the conditions of thermodynamic equilibrium, for the analyzed $(\mathrm{Ti}, \mathrm{V})(\mathrm{C}, \mathrm{N})$ carbonitrides are listed in Table 3.

The thermodynamic-equilibrium solubility temperature of $\mathrm{Ti}_{0.928} \mathrm{Nb}_{0.072} \mathrm{C}_{0.140} \mathrm{~N}_{0.860}$ in steel B is $1361{ }^{\circ} \mathrm{C}$ (Figure 2). The thermodynamic analysis of the precipitation of the investigated carbonitrides allows us to state that its volume fraction in austenite $V_{\mathrm{v}}=f(T)$ increased up to about amount fraction $0.14 \%$ due to a decrease in the temperature to $850{ }^{\circ} \mathrm{C}$. The decrease in the temperature from $1300{ }^{\circ} \mathrm{C}$ to $1100{ }^{\circ} \mathrm{C}$ causes a relative decrease in the $\mathrm{Ti}$ concentration and an increase in the $\mathrm{Nb}$ concentration. By further lowering the temperature to $850{ }^{\circ} \mathrm{C}$ a mild decrease in the $\mathrm{Ti}$ amount and a slight increase in the $\mathrm{Nb}$ amount occur; an increase in the $\mathrm{V}$ amount fraction to $0.11 \%$ in the analyzed carbonitride occurs in the temperature range from $1100{ }^{\circ} \mathrm{C}$ to $850{ }^{\circ} \mathrm{C}$. By analyzing the amounts of the interstitial elements in the investigated carbonitride, it was found that the carbon concentration at $1361{ }^{\circ} \mathrm{C}$ is $0.14 \%$ and it increases up to $0.75 \%$ at $850{ }^{\circ} \mathrm{C}$. In the examined temperature range the
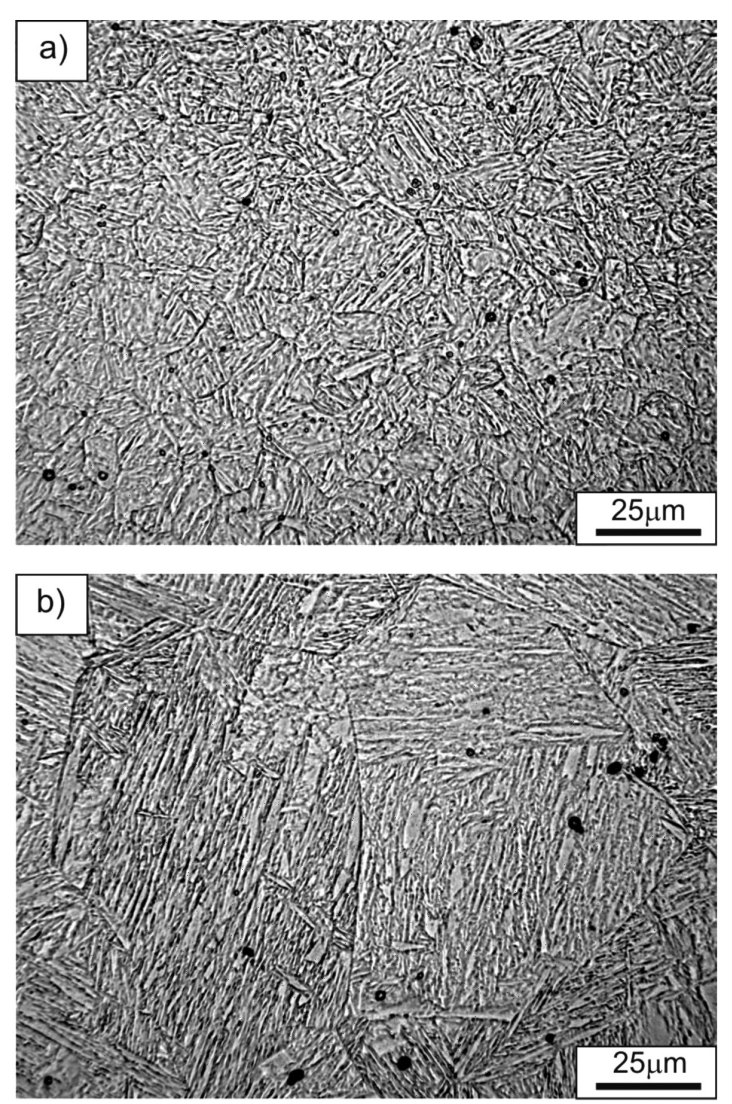

Figure 3: Austenite grains and MX particles in steel A; austenitizing temperatures of: a) $900{ }^{\circ} \mathrm{C}$ and b) $1200{ }^{\circ} \mathrm{C}$

Slika 3: Avstenitna zrna in MX-delci v jeklu A; temperatura avstenitizacije: a) $900{ }^{\circ} \mathrm{C}$ in b) $1200{ }^{\circ} \mathrm{C}$ 

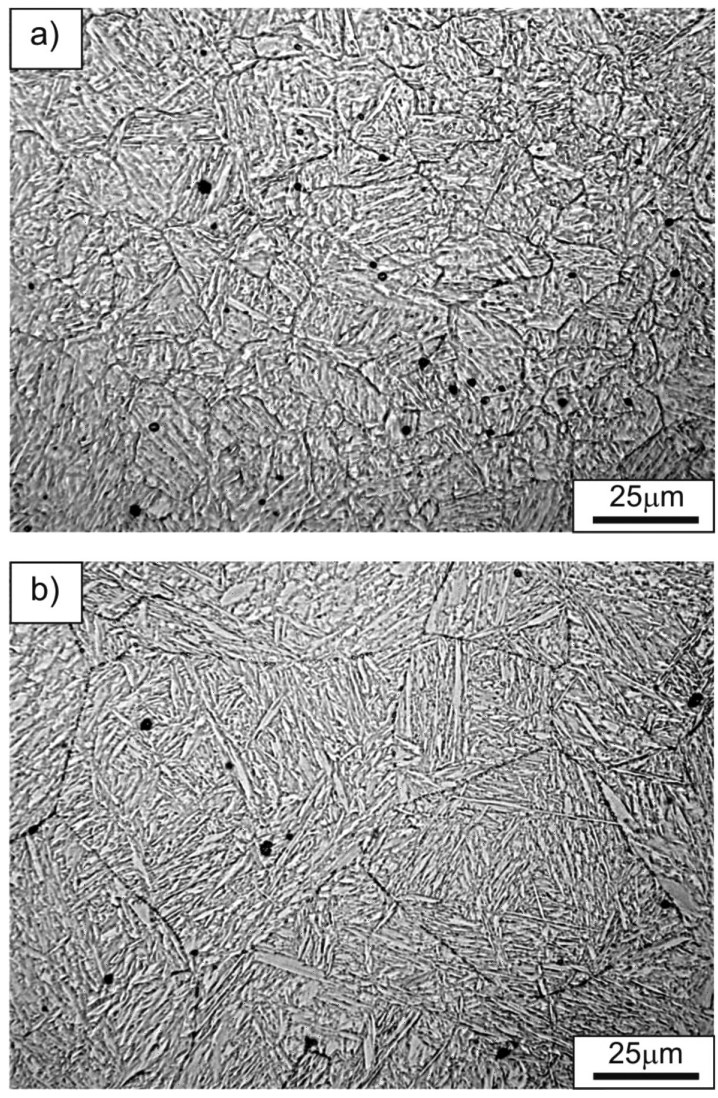

Figure 4: Austenite grains and MX particles in steel B; austenitizing temperatures of: a) $900{ }^{\circ} \mathrm{C}$ and b) $1200{ }^{\circ} \mathrm{C}$

Slika 4: Avstenitna zrna in MX delci v jeklu B; temperatura avstenitizacije: a) $900{ }^{\circ} \mathrm{C}$ in b) $1200{ }^{\circ} \mathrm{C}$

changes in the nitrogen amount are opposite to the changes in the amount of carbon.

The effect of the temperature from $900{ }^{\circ} \mathrm{C}$ to $1200{ }^{\circ} \mathrm{C}$ on the austenite grain size was investigated to verify the results of the calculation of the precipitation of MX particles. Austenite grains and particles are presented in Figures 3 and 4, while Figure 5 shows the effect of the temperature on the average size of the austenite grains at a given temperature. The size of the austenite grains at $900{ }^{\circ} \mathrm{C}$ to $1000{ }^{\circ} \mathrm{C}$ is very small, from $11 \mu \mathrm{m}$ to $18 \mu \mathrm{m}$ in the Ti-V steel and $8 \mu \mathrm{m}$ to $12 \mu \mathrm{m}$ in the Ti-Nb-V steel. This fine-grained microstructure is a result of the presence of significant fractions of the $(\mathrm{Ti}, \mathrm{V})(\mathrm{C}, \mathrm{N})$ particles and complex $(\mathrm{Ti}, \mathrm{Nb}, \mathrm{V})(\mathrm{C}, \mathrm{N})$ carbonitrides (respectively for the A and B steels) that effectively inhibit the growth of the austenite grains. An increase in the temperature causes a gradual growth in the austenite grains, more distinct for the $\mathrm{Nb}$-free steel (Figure 5). The average diameters of the austenite grains after austenitizing the steels at the temperature of $1200{ }^{\circ} \mathrm{C}$ are 66 $\mu \mathrm{m}$ and $62 \mu \mathrm{m}$ for the A and B steel, respectively. These values are several times lower compared to the $\mathrm{C}-\mathrm{Mn}$ steels, where a typical austenite grain size at $1200{ }^{\circ} \mathrm{C}$ is reported to be from $200 \mu \mathrm{m}$ to $300 \mu \mathrm{m} .{ }^{1,4}$ The observed grain sizes of the austenite for the investigated steels are

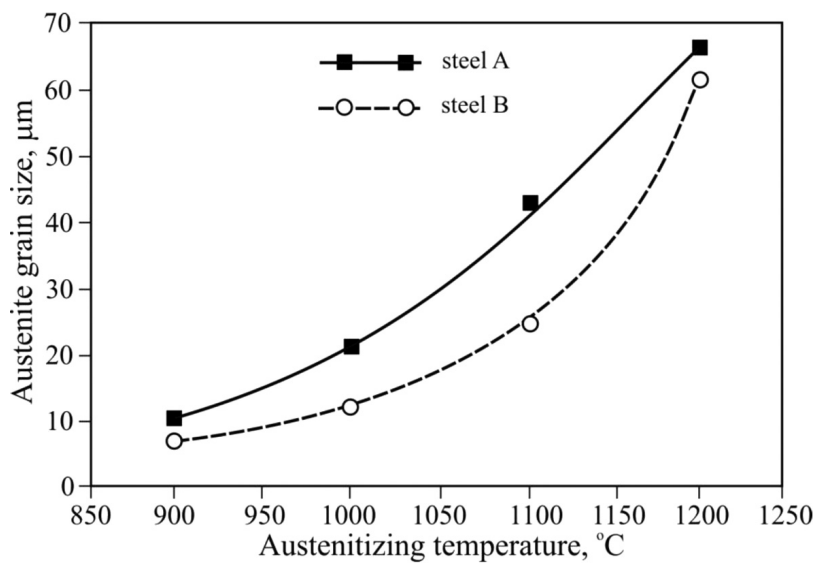

Figure 5: Influence of the austenitizing temperature on the austenite grain size

Slika 5: Vpliv temperature avstenitizacije na velikost avstenitnih zrn

also similar to those reported for the other Ti-V or Ti-Nb steels. ${ }^{4,14-17}$

The austenite grain growth in steel A is mainly controlled with the $(\mathrm{Ti}, \mathrm{V})(\mathrm{C}, \mathrm{N})$ particles generally precipitating above $1200{ }^{\circ} \mathrm{C}$. The curve in Figure 5 for the $\mathrm{Nb}$ steel is characteristic for microalloyed steels and the grain growth can be combined with the precipitation process of complex carbonitrides. Due to the gradual dissolution of the Nb-rich MX-type phases, the austenite grain size increases gradually with the increasing austenitizing temperature and the growth is much faster above $1100{ }^{\circ} \mathrm{C}$. At $1200{ }^{\circ} \mathrm{C}$ the fractions of the particles in both steels are comparable, consisting only of the Ti-rich MX-type phases that lead to similar austenite grain sizes.

\section{CONCLUSIONS}

The simplified-thermodynamic-model analysis of the precipitation of the MX-type phases in both steels found the highest thermal stability in the austenite of TiN. The TiN precipitation starts at around $1350{ }^{\circ} \mathrm{C}$. The $\mathrm{TiC}$ precipitation occurs in the temperature range from 1150 ${ }^{\circ} \mathrm{C}$ to $1200{ }^{\circ} \mathrm{C}$. It was shown in ${ }^{1,4,14,17,18}$ that the MX-type phases show mutual solubility. Hence, the austenite grain growth in steel A should be controlled with complex (Ti, $\mathrm{V})(\mathrm{C}, \mathrm{N})$ carbonitrides. More complex carbonitrides are found in the $\mathrm{Ti}-\mathrm{Nb}$ steel and the grain growth in steel $\mathrm{B}$ is controlled with the precipitation of the $(\mathrm{Ti}, \mathrm{Nb}, \mathrm{V})(\mathrm{C}$, N) particles.

The analysis of the precipitation of the MX-type phases in austenite allows us to select a proper forging temperature range, which should correspond to the temperature range of the precipitation of these phases. High mechanical properties of forged parts can be achieved with an appropriate selection of the forging conditions, i.e., the temperature of charge heating and the plastic deformation range since the distribution of the strain and strain rate during the production of die forgings with a 
complex shape is difficult to adjust. Forge heating should not lead to a total dissolution of the interstitial elements in the solid solution because it causes a grain growth. Hence, the A and B steels may be heated up to the forging temperature of $1200{ }^{\circ} \mathrm{C}$, without an excessive growth of the austenite grains.

The investigation of the influence of the austenitizing temperature on the austenite grain size confirms the correctness of the precipitation analysis of the MX phases in the investigated steels. The steels have a finegrained austenite over the whole investigated austenitizing temperature range. In both steels the austenite grain size grows with the increasing temperature and it is several times lower in comparison to the C-Mn steels. A faster grain growth is observed for the Ti-V steel. In the $\mathrm{Nb}$ steel, the grain growth is delayed due to $\mathrm{Ti}$ and $\mathrm{Nb}$ combined microalloying, resulting in a slower dissolution of the complex $(\mathrm{Ti}, \mathrm{Nb}, \mathrm{V})(\mathrm{C}, \mathrm{N})$ particles.

The performed analysis of the precipitation process of the MX-type phases provides the basis for a suitable design of the thermomechanical processing of microalloyed steels for high-strength forged machine parts.

\section{REFERENCES}

${ }^{1}$ T. Gladman, The physical metallurgy of microalloyed steels, $1^{\text {st }}$ ed. The University Press, Cambridge 1997

${ }^{2}$ J. Adamczyk, Journal of Achievements in Materials and Manufacturing, 20 (2007), 399-402
${ }^{3}$ M. Opiela, A. Grajcar, Arch. Civ. Mech. Eng., 12 (2012), 327-333, doi:10.1016/j.acme.2012.06.003

${ }^{4}$ R. Kuziak, T. Bold, Y. Cheng, J. Mater. Proc. Tech., 53 (1995), 255-262, doi:10.1016/0924-0136(95)01986-L

${ }^{5}$ J. Adamczyk, E. Kalinowska-Ozgowicz, W. Ozgowicz, R. Wusatowski, J. Mater. Proc. Tech., 53 (1995), 23-32, doi:10.1016/0924-0136 (95)01958-H

${ }^{6}$ H. Adrian, Proc. of the Inter. Conf. Microalloying '95, Iron and Steel Soc., Pittsburgh, 1995, 285-305

${ }^{7}$ E. J. Palmiere, Proc. of the Inter. Conf. Microalloying '95, Iron and Steel Soc., Pittsburgh, 1995, 307-320

${ }^{8}$ D. A. Skobir, M. Godec, M. Balcar, M. Jenko, Mater. Tehnol., 44 (2010) 6, 343-347

${ }^{9}$ A. Grajcar, S. Lesz, Mater. Sci. Forum, 706-709 (2012), 2124-2129, doi:10.4028/www.scientific.net/MSF.706-709.2124

${ }^{10}$ M. Hillert, L. I. Staffanson, Acta Chem. Scand., 24 (1970), 3618-3636, doi:10.3891/acta.chem.scand.24-3618

${ }^{11}$ H. Adrian, Scientific Editions of University of Mining and Metallurgy, Kraków, 1995

${ }^{12}$ H. Adrian, Mater. Sci. Technol., 8 (1992), 406-415

${ }^{13}$ M. Opiela, Journal of Achievements in Materials and Manufacturing, 47 (2011), 7-18

${ }^{14}$ D. K. Matlock, G. Krauss, J. G. Speer, J. Mater. Proc. Tech., 117 (2001), 324-328, doi:10.1016/S0924-0136(01)00792-0

${ }^{15}$ M. MacKenzie, A. J. Craven, C. J. Collins, Scri. Mater., 54 (2006), 1-5, doi:10.1016/j.scriptamat.2005.09.018

${ }^{16}$ P. S. Bandyopadhyay, S. K. Ghosh, S. Kundu, S. Chatterjee, Metall. Mater. Trans. A, 42 (2011), 2742-2752, doi:10.1007/s11661-0110711-2

${ }^{17}$ A. Nowotnik, T. Siwecki, J. Microsc., 237 (2008), 258-262, doi:10.1111/j.1365-2818.2009.03238.x

${ }^{18}$ M. Opiela, A. Grajcar, Arch. Civ. Mech. Eng., 12 (2012), 427-435, doi:10.1016/j.acme.2012.06.013 